Article

\title{
Why the West Could Not Hear Beale Street: Baldwin's World-Sense of Female Sexuality
}

\author{
Amy Yeboah $(1)$ \\ Department of Afro American Studies, Howard University, Washington, DC 20059, USA; \\ amy.yeboah@howard.edu
}

Received: 22 July 2019; Accepted: 7 January 2020; Published: 10 January 2020

\begin{abstract}
While scholars have noted James Baldwin's revisionary and transformative literary approach to social constructions of race, class, gender, and crime, there has been very little conversation in that vein regarding If Beale Street Could Talk (1974). Upon its publication, many critics issued negative reviews of the novel, failing to recognize how Baldwin's view of female sexuality both embraced notions of the body and constructs from an African-centered world-sense. Using a range of theoretical resources from Africana Studies, this paper analyzes how moving beyond Western frameworks regarding knowledge, sexual discourse, and behavior offers a new interpretation of Baldwin's aims that reclaims and re-imagines Black sexual politics.
\end{abstract}

Keywords: sexuality; love; beauty; Africa; Black love; intimacy; spirituality; worldview; world sense; sex

\section{Introduction}

For centuries, literature has been a forum for not merely highlighting controversies and tensions over sexual politics and behavior in American society but furthering the conversation about these complex issues. Yet, the experiences of people of African descent with respect to gender, sex, and sexuality, and particularly Black women, have typically been unseen, unanalyzed, and untheorized (Higginbotham 1989; Hammonds 1999). A notable if often overlooked exception is James Baldwin's 1973 novel If Beale Street Could Talk. Against the one-dimensional cultural backdrop of the 1970s blaxploitation films featuring pimps, prostitutes, and street hustlers stooped in plots of sex, violence, and drugs, Baldwin would have the temerity to publish a romance set in the "poor, black world of streets and stoops and store-front faith", which he proclaimed to his brother David to be "the strangest novel [he had] ever written"- - one that gives voice to the Black female sexual experience from a distinctively non-Eurocentric vantagepoint (Baldwin 1973).

Multiple scholars acknowledge Baldwin's unique and transformative literary approach in grappling with the tensions surrounding the social constructions of race, class, and even law (Gounard 1992; McBride 1999; Balfour and Balfour 2001; Miller 2012). However, little has been said about Baldwin's African-centered presentation and analyses of sex, sexuality, and Black womanhood. Critics that have commented on Baldwin's treatment have done so from an unreflective Eurocentric perspective, one that privileges the Black body over Black beauty, focuses on Black control over Black freedom, and sees Black sex rather than Black intimacy. Yet, with the surge of scholarship within the field of Africana Studies, the cultural and institutional recognition of the importance and diverse experiences of Black women (encapsulated in the intersection of the \#BlackLivesMatter and \#MeToo movements), and even the recent film treatment of the novel by director, producer, and screenwriter Berry Jenkins, the time appears ripe to revisit Baldwin and examine his approach. This essay analyzes the cultural tropes and rhetorical strategies Baldwin uses to depict a modern Africana sense of sexual philosophy, discourse, 
and behavior. I argue If Beale Street Could Talk takes the reader on a journey through the voice and perspective of a Black woman to reimagine sexual politics for people of African descent.

\section{Reception: A Rejection of Baldwin}

Baldwin had not published a novel in five years when If Beale Street Could Talk emerged in 1973, and many mainstream white reviewers of Baldwin's novel dismissed it out of hand. Writing for The New York Times, Anatole Broyard declared that regarding the experience of members of the African diaspora in America, Baldwin had already "picked that particular bone clean" (Broyard 1974, p. 37). He launched a full-throated assault against the novel, seeing only a text riddled with clichés wrapped around a "vehemently sentimental love story":

Fonny and Tish are planning to get married and move to the garbage-piled streets of the Lower East Side, when Fonny is framed on a rape charge by a white racist policeman. While Fonny fights off real rapists in "the unimaginable inferno" of a city prison, Tish reveals that she is pregnant ... Her dual predicament-Fonny in jail and the baby in her belly-sets everybody to moralizing. The most banal remarks are pregnant, too, with philosophical overtones ... After visiting Fonny in jail, Tish hopes "that nobody has ever had to look at anybody they love through glass". (Broyard 1974, p. 37)

Broyard doesn't stop his critique of the prose there, going on to observe that "Tish talks as if love had alienated her from her normal speech patterns" and describing Baldwin's prose as "stale jazz". His final verdict dismisses Baldwin as "so dated". (Broyard 1974, p. 37)

Reviewers outside of America were equally unkind, with Peter Ackroyd complaining in the Spectator about Baldwin's "mawkish" style, "cardboard" characters, and plot lines where "[w]hite policemen and spinsters are always very bad" (Broyard 1974, p. 22). His complaints echo earlier reviews of Baldwin's 1968 novel Tell Me How Long the Train's Been Gone, where critic Mario Puzo (of Godfather fame) observed of that earlier effort that "[Baldwin] has not been successful; this is a simpleminded, one-dimensional novel with mostly cardboard characters..". and described him as "not a true or 'born' novelist", but instead just a race spokesman (Puzo 1968, p. 484). Ackroyd's view of Baldwin's skills as a novelist are revealed by his unsubtle hesitancies: "I suppose" Fonny being sent to jail adds "depth to their romance"; "apparently" Baldwin's vision of experience of Black America "remains untarnished with the passing of his years"; his manner is fervour "(if fervour is an advantage)"; and so on (Ackroyd 1974, p. 22). His critique of Baldwin's writing equally lays bare his Westernized prejudices: Baldwin fails because he uses "the same impassioned prose" as in earlier novels "as if" it were "the hallowed container of sacred meanings" (Ackroyd 1974, p. 37). Ackroyd's review appears to recognize the inventive and destabilizing effect of Baldwin's choice of narrator when he remarks that "Baldwin is a professional fugitive; he is always on the run ... his final trick [is] he escapes from his own sex in If Beale Street Could Talk", but he refuses to recognize Baldwin's choice as theoretically important, citing it as the "last straw" of a failed novelist (Ackroyd 1974, p. 37). Needless to say, the fact that Baldwin's story "disobeys the conventional laws of narrative" is not said with praise (Ackroyd 1974, p. 22).

Overall, many reviewers considered If Beale Street Could Talk as a "flop" (Nishikawa 2019). Even fellow author Joyce Carol Oates's overall positive review did not escape from framing Baldwin's novel as a "very traditional celebration of love" whose prose contained no "tricks" and whose characters are portrayed simply as victims: "blacks constantly at the mercy of whites [who] have not even the psychological benefit of the Black Power and other radical movements to sustain them ..." (Oates 1974, p. 376).

Yet, on my reading of the text, the novel's contemporaneous critical reception was blind to Baldwin's intensions. There is nothing traditional about Baldwin's presentation of Black love, his narrative style, nor his characterization of the female protagonist Tish (and the central voice of the 
novel). Reading these reviews, one would think that the novel was written by a rank amateur rather than an accomplished writer like Baldwin-just another miserable love story about a pregnant Black teenage girl and her unlawfully criminal Black boyfriend. However, a closer look at reviews like Broyard's reveals the blinders and biases through which he and others read the novel. For example, instead of discussing the love story that forms the core of the narrative, the word "love" is strangely absent in his review, referred to just twice (and in scathing terms). Instead, Broyard's take on the novel is replete with mention of words like jail, chains, pregnancy, baby, and even Tish's belly, consistently revealing a Western framework that centralizes Black bodies. Such criticisms align with Dorothy Roberts' ([1997] 2007) analyses of historical reproductive oppressive images and language used to infringe and criminalize Black women's bodies.

As I will argue below, critics frame Baldwin's text using Western standards that view bodies and sexual politics as sites of conflict, disharmony, and power relations. Such lenses systemically misinterpret and devalue the views and behavior of Black people and Black writing about them. To counter such readings, this paper positions Baldwin's writing within an Africana studies paradigm. ${ }^{1}$ Methodologically coming from an African world-sense, this is a process of "tracing and re-tracing the African experience from its [long-view] origins in Africa to the present" (Carr 2006). Like many Black writers in the decade of the Harlem Renaissance and Black Arts Movement, Baldwin centers Black thought, life, and experiences. Through the prism of Baldwin's novel and specifically his protagonist Tish, Baldwin's focus was not in narrating difference or sameness with the West, but I will argue, rather speaking about, with, and to a complex Black experience. As a result, his approach challenges common assumptions grounded in Western notions of a worldview and visualizations of the body, especially black women's bodies being sites of control and distress.

Once re-examined, Baldwin's sexual politics in If Beale Street Could Talk reveals his writing as centering cultural and social norms about the Black body and especially Black women. This approach systematically connects back to an African world-sense. Through the gaze of a Black woman narrator, Baldwin radically reconceptualizes what the love between Tish and Fonny might be in terms of invisible familiarities and silent symbolic representations. Tish is brave, bold, loving, smart, and protective, unlike stereotypes of being a sexualized jezebel. Despite growing up in the harsh conditions of New York City, her dialogue is heartfelt, metaphorical, poetic, and funny, not the overly vulgar, combative, and manipulative language of the street. Although she grapples with being sexually assaulted and the historical legacy of slavery and racism within the criminal justice system, Baldwin's presentation of Tish' imagination is authentic, romantic, dramatic, and dynamic, making love the true hero against white supremacy. If read through this lens, upon reaching the end of Baldwin's novel, the reader is left with a radically African-centered world-sense of a Black woman's sexual experience.

\section{Philosophy: The World-Sense of Presence}

There are a number of sources where one might look to discover a historical understanding of the Western worldview of the body. For instance, Thomas Laqueur's Making Sex: Body and Gender from Greeks to Freud catalogues the numerous ways the Western worldview encapsulates a view that biology is destiny (1990). From the outset, it was understood that "man is the measure of all things" and the body was determined (Laqueur 1990, p. 62). Bryan Turner's The Body \& Society in 1996 would extend the conversation to observe that the body in the West is a "sign of the good life and an indicator of cultural capital" (Turner 2008, p. 3). Such views elevated the body into the realm of transcendental knowledge, rooted and grounded in the interplay of property, wealth, justice, religion, and marriage. Women's bodies, according to this outlook, are the primary mechanism through which one can view the political struggle over the economic, social, sexual, racial, and even technological understanding of what it is to be a woman. Anna Clark's Desire: A History of European Sexuality would extend the

1 The disciplinary term African Studies in this context refers to the study of Africans and African-descended communities. 
same central conversation about the body and control as it pertains to sexuality and desires in the West (2019). These works spell out the manifold ways in which information and understanding is encoded in the importance of the body, especially for women in a variety of somatic encounters.

Baldwin plainly rejected the Western categories associated with the body, and in particular with how women's bodies are constructed in the West. In a conversation with Audre Lorde in 1984, Baldwin said,

We get confused with genders-you know, what the Western notion of woman is, which is not necessarily what a woman is at all. It's certainly not the African notion of what a woman is. Or even the European notion of what a woman is. (Lorde and Baldwin 1984, p. 48)

In Baldwin's 1955 publication of Notes of a Native Son, Baldwin also states,

I love America more than any other country in the world, and, exactly for this reason, I insist on the right to criticize her perpetually. I think all theories are suspect, that the finest principles may have to be modified, or may even be pulverized by the demands of life, and that one must find, therefore, one's own moral center and move through the world hoping that this center will guide one aright. (Baldwin 1955, p. 9)

A closer look at his novel If Beale Street Could Talk reveals that Baldwin opted for an outlook and moral center far more African than Western.

Through the emergence of Black Studies (also known today as Africana Studies) as a discipline in the 1960s, multiple scholars have offered useful theoretical lens from which to view Baldwin's challenge to the notion that a Western worldview is the only way of understanding, and that the bodies of women are the primary site of contention for understanding their sexuality. For example, Nigerian scholar Oyèrónké Oyěwùmí, in her The Invention of Women: Making an African Sense of Western Gender Discourses, challenges Western notions of "worldview", a construct that privileges the biological visualization of the body (i.e., skin color, sex, gender, etc.) through a universal gaze. Oyěwùmí suggests the term "world-sense" as a more inclusive way of describing the diverse forms of knowing beyond sight, especially for African people. In using Yorúbá society as a model, Oyěwùmí argues that the body is not the only basis for social classification and understanding. Unlike in Western cultures, in Yorúbá society, historically “the social categories 'men' and 'women' were nonexistent, and hence no gender system was in place" (Oyěwùmí 1997, p. 31). Like Oyěwùmí, Baldwin constructs a narrative "world-sense" in his novel whose expressions of sexuality, gender, and desire seem to explicitly and implicitly reject a Western worldview.

Take, for instance, how Baldwin's narrative first opens up the question of "who are they" through Tish's complex description of her and Fonny's childhood. As the reader wonders about how deep this love story is, Baldwin invites the reader to enter into Tish's perspective and re-live what it was like to be a part of their love. In doing so, he radically undercuts the Western picture of bodily love in favor of something much more African in its outlook:

I dumped water over Fonny's head and scrubbed Fonny's back in the bathtub, in a time that seems a long time ago now. I swear I don't remember seeing his sex, and yet, of course, I must have. We never played doctor-and yet, I had played this rather terrifying game with other boys and Fonny had certainly played with other girls, and boys. I don't remember that we ever had any curiosity concerning each other's bodies at all-due to the cunning of that watching moment which knew we were approaching. Fonny loved me too much, we needed each other too much. We were a part of each other, flesh of each other's flesh-which meant that we so took each other for granted that we never thought of the flesh. He had legs, and I had legs—-that wasn't all we knew but that was all we used. They brought us up the stairs and down the stairs and, always, to each other. (Baldwin [1974] 2018, pp. 50-51).

Even at a young age, Tish focuses not on Fonny's flesh but her strong sense of connection to him. Baldwin eloquently describes Tish's desire and love for Fonny without placing it in sexual terms, 
and Fonny freely expresses his love for her. Their love is not conditioned on their bodies- 'I don't remember that we ever had any curiosity concerning each other's bodies at all" - and rather than inhabiting separate bodies they share a sense of their world that transcended being individuals. Baldwin's love story drives this point home by reconceptualizing the language of Genesis 2:23. Whereas the Bible states "This is now bone of my bones and flesh of my flesh; she shall be called 'woman', for she was taken out of man", positioning woman as secondary to and an extension of man, Baldwin puts Tish and Fonny's connection on an equal footing: "flesh of each other's flesh" (Baldwin [1974] 2018, p. 51). Tish and Fonny's love in Tish's telling is so much more than two physical bodies joining together-Baldwin frames it as transcending the physical through an emotional and spiritual lens.

Within the text, Baldwin centers an African world-sense of the body by introducing the concept of a "presence" that authentically guides and gives the reader a deeper sense of Tish and Fonny's desires. This type of expression and understanding of personhood is found in the Akan peoples of Ghana. For the Akan, the "presence" of an individual is a composition of many factors-of mogya (blood) and honam (body), which represent the physical components, and kra (life force/soul), honhom (breath of Divine Life), and sunsum (spirit), which represent the spiritual components. Children, for example, are conceived when the mogya of the mother comes together with the sunsum of the father (Gyekye 1995), and the other components of the child's "presence" are added over time, with no fixed universal "essence" that defines the individual.

Such a world-sense of personhood reflects a deeper sense of how Tish views herself and her relationship with Fonny. Separated by prison bars and a wall of glass, Baldwin articulates a deeper understanding of his protagonists' love. Instead of asserting her individuality or focusing on her bodily existence, Tish speaks of her "presence" as the essential part of her in their relationship:

My presence, which is of no practical value whatever, which can even be considered, from a practical point of view, as a betrayal, is vastly more important than any practical thing I might be doing. Every day, when he sees my face, he knows, again, that I love him-and God knows I do, more and more, deeper and deeper, with every hour. But it isn't only that. It means that others love him, too, love him so much that they have set me free to be there. He is not alone; we are not alone. (Baldwin [1974] 2018, p. 162)

Tish's "presence" is an articulation less of her honam (body), but rather of her kra (life force/soul). Her life force and soul are "vastly more important" than her physical face, liberating her from negative stereotypes around the Black body. To focus on her body would be a "betrayal" because what is beautiful about her is the love she has for him-a love that only God can fully plumb the depths of. But that love is not bounded by her alone-her "presence" carries with it the "presences" of others who love him as well, enveloping him—and by extension them ("we")—in an all-encompassing love.

That sense of collective unity that Baldwin captures when Tish reflects that "It means that others love him, too ... " (Baldwin [1974] 2018, p. 162) can be seen in how Fonny and Tish's family to take part in what Fonny sees as attractive about Tish. The love her family has for Fonny moves them to work exceptionally hard to bail him out of jail, find him a good lawyer, and even travel to Puerto Rico to convince his accuser that Fonny did not rape her. Such actions reflect what Africana Psychologist Azibo (1992) articulates as the shared world-sense families have of "how a people see their reality [and] how things should be" (p. 70). This African-centered ideology connecting others is reflected in her actions and the actions of her family-actions that transcend the fact that Fonny is imprisoned and literally cannot physically be present.

Baldwin drives home the point of the body's irrelevance when it comes to how Tish recounts her sexual experience with Fonny. Characterizing their union as a "sacrament", and their baby as "best thing that ever happened" Tish states "... the effect was as of some strange anointing ... And Fonny's body was a total mystery to me" (Baldwin [1974] 2018, p. 81). Rather than ruminating over whether Fonny had sex with Tish, or what kind of sexual contact they had-which privileges their 
bodies-Baldwin redirects his readers attention to the kind of love Tish and Fonny have- the kind of love that is "a miracle". Doing so breaks away from Western assumptions of sexual behavior, control, and possession of the body, steeped in degrading mythology about Black women and mothers (Roberts 2007).

Perhaps most striking of all is when Tish first recognizes Fonny's body. For a long time, Tish does not see Fonny's body, yet when she does, instead of seeing him, she recognizes her own body:

His face was bigger than the world, his eyes deeper than the sun, more vast than the desert, all that had ever happened since time began was in his face. He smiled: a little smile ... It's astounding the first time you realize that a stranger has a body-the realization that he has a body makes him a stranger. It means that you have a body, too. You will live with this forever, and it will spell out the language of your life. (Baldwin [1974] 2018, p. 52)

This passage works to destroy oppressive social discourses against the Black body. When Tish visualized Fonny's body, she does not see society's negative stereotypes, with the female body being an inverted and weaker version of the male body (Laqueur 1990). Instead, Baldwin develops a deeper conversation about the sexual connection between men and women with the moment of realization triggering in herself as a positive human reflection. When Tish sees Fonny's body, she sees herself, and in the transcendent power of his smile, discovers an equality that the West twice denies Black women on the basis of their race and gender. From this moment of recognition, Baldwin sees Tish using the "language" of the life and love she has for Fonny to fashion a distinct non-Western discourse to explain the deeper world-sense of the love they have for one another.

\section{Discourse: Beauty and Silence}

Over the span of Western history, language about sex has reflected concepts of dominance, aggressiveness, and even shame and humiliation in many cases (Skinner 2005; Winkler 2013; Davidson 2007). Western playwrights, artists, philosophers, and writers have depicted this power through male control, stemming as far back as the Greeks. For example, Austin and Olson's (2004) analysis of the stage directions for Aristophanes' play Thesmophoriazousai showcase the pervasiveness of the attitudes surrounding sex and domineering discourse used in describing it:

... the narrator has sex with her boyfriend in the street rather than going inside somewhere is further proof of her shamelessness ... This is the first of three crude verbs Inlaw uses to describe intercourse, all of which tacitly endorse the notion that what women want out of sex is simply to have an erect penis thrust into them as hard as often as possible. (p. 201)

Austin and Olson find no descriptions of gentle embraces, consensual foreplay, or even just sweet words passing between lovers. Even as the discourse regarding sexual desire evolved from the Greek "force of nature" to the Christian "temptation of the devil" it still remained centered on control and dominance (Clark [2008] 2019, p. 2). In contrast, according to Jomo Kenyatta in Facing Mount Kenya: The Tribal Life of the Gikuyu,

In order not to suppress entirely the normal sex instinct, the boys and girls [after their rites of passage rituals] are told that in order to keep good health they must acquire the technique of practicing a certain restricted form of intercourse, called ombani na ngweko (platonic love and fondling). This form of intimate contact between young people is considered right and proper and the very foundation stone upon which to build a race morally, physically and mentally sound. (Kenyatta 1962, p. 155)

As the emergence of Romanticism took place in the end of the 18th century, conversations around love would continue to marginalize or even deny the existence of alternative discourses of sex, love, desire, beauty, and romance rooted in the Africana experience. In the words of Paul Youngquist and Frances Botkin, "the whiteness of Romantic studies is a symptom of amnesia" 
(Youngquist and Botkin 2011, p. 1). The West's inability to recognize or understand alternative sexual discourses, especially regarding Black women, leads to marginalizing or misunderstanding their world-sense. In If Beale Street Could Talk, Baldwin offers a corrective to this amnesia, presenting the reader with an intoxicating African-centered narrative regarding the love shared between Tish and Fonny, tapping the resources of multiple Africana perspectives to express his vision through words and silences.

Baldwin's novel is a romance, so it comes as no surprise to discover him using the language of love. There are over 100 instances where he employs variations on the word "love", with Tish repeatedly stating how she "loves" Fonny/him, even saying "love you Fonny" multiple times. However, underneath those declarations of love is an understanding of what love constitutes. Instead of an infatuation with Fonny's body, what Tish repeatedly states is how much she loves his beauty, which is intimately linked to his innocence: "I know [Fonny has] never committed any crime and he is a beautiful person" (Baldwin [1974] 2018, p. 8). Over and over Baldwin uses the terms "beauty" and "beautiful" to describe Tish and Fonny's relationship, making Tish circle back to mention Fonny's beauty (a very un-masculine description in the West) two dozen times in the novel. However, it is clear that Baldwin does not mean that Tish primarily sees Fonny's physical beauty. Instead, Tish sees his "presence": "He's beautiful. They beat him up, but they didn't beat him—if you see what I mean. He's beautiful" (Baldwin [1974] 2018, p. 196). Baldwin's views are in alignment with Black feminist theorist, historian, and scholar Hammonds (1999), who sees Black women "engaged in a process of fighting to reclaim the body-the maimed, immoral, black female body-which can be and is still being used by others to discredit them as producers of knowledge and as speaking subjects" (p. 99). Tish's voice, emotions, and perspective dominates the narrative and centers her as a producer of her own knowledge.

The idea that beauty can mean more than just the physical is encapsulated by "ewà", the Yoruba word for beauty. According to Hallen in The Good, the Bad, and the Beautiful: Discourse about Values in Yoruba Culture, the term's "most common usage was emphatically with regard to persons" associating not with material items or physical characteristics but a person's inner beauty (Hallen 2000, p. 114). For Baldwin, it is this inner beauty this is the focus. It is the hinge upon which Tish's love for Fonny rests. Indeed, because their physical encounters are limited due to Fonny's jail sentence, both able to experience their love on a profoundly non-physical plane.

Within African culture, non-verbal expressions are as equally important as verbal expressions. Just as oral literature is as equally important as written literature, silences are not seen as absences but as on par with the spoken word (Okpewho 1992). This outlook stands in stark juxtaposition with the West. Patrick Hogan in Philosophical Approaches to the Study of Literature presents a convincing body of evidence to illustrate the Western belief in the inherent superiority of sounds and speech (2001). Central to that paradigm is the marginalization of the voices of women: "it is part of the discursive history in which the speech of women and the status of that speech is contested" (Hogan 2001, p. 196). Unlike in an African-centered context, where silences can signal profundities, the silence of women in the West is a sign that they have nothing of worth to say.

Baldwin also incorporates profound silences, thoughts unsaid, and metaphorical allusions in the lack of words that pass between Tish and Fonny to signal the depth of their love:

I was so happy to see him, after so long, that I was ready to cry. And everything was different. I was walking through streets I had never seen before. The faces around me, I had never seen. We moved in a silence which was music from everywhere. Perhaps for the first time in my life, I was happy and knew that I was happy, and Fonny held me by the hand. (Baldwin [1974] 2018, pp. 51-52)

Then, he stopped grinning and a kind of stinging silence filled the room and filled my ears. It was like nothing was happening in the world but us. I was not afraid. It was deeper than fear. I could not take my eyes away from his. I could not move. If it was deeper than fear, it was not yet joy. It was wonder. (Baldwin [1974] 2018, p. 75) 
... in complete silence, without moving a muscle, we are laughing with each other. We are laughing for many reasons. We are together somewhere where no one can reach us, touch us, joined. (Baldwin [1974] 2018, p. 105)

The silence they experienced was "music", triggering feelings of "wonder", and culminating in the ineffable experience of joyous laughter that transported them to a realm not even prison bars can touch. Despite the crush of the physical world impinging on Fonny's body, Tish remains tethered to him, their bond strong despite the obstacles the Western world sets against them. Baldwin captures their connection in the absence of words-and absence that signals not a lack, but a profundity.

As many scholars debate the silencing of Black women in literature, Tish's silence in Baldwin's If Beale Street Could Talk speaks volumes. The phrases "We moved in a silence", moments of "stinging silence", and "complete silence" exemplify the strong nonverbal connection Tish and Fonny hold-that their love transcends the need to be communicated with words, speech, and bodies. For Baldwin, silence is a not the absence of presence, but an active component of human discourse.

Yet, of course, Tish is the narrator of the novel as well, and placing a young Black female's voice at the center of the work is to turn the West's marginalization of those voices on its head. The discourse Tish employs in If Beale Street Could Talk is intimate, vibrant, and dynamic. With the most ordinary words being delivered with such reverence and meaning, Baldwin's aesthetic choices carry a purposeful tone set against the dialogical structures of the West. Despite having a child out of wedlock, being young and Black in New York City, struggling to build a family, and dealing with a racist criminal justice system, line by line Tish and Fonny's deep emotional connection remains at the forefront. Baldwin does not hold back in having Tish express the intensity of the love she has Fonny, but does so in ways the defy the claims of critics that their love is a "very traditional celebration of love" or worse "a vehemently sentimental love story". The evidence, in fact, is quite to the contrary, but only if one breaks free of the Western paradigms of discourse about sex and love.

\section{Behavior: Intimacy over Sex}

As the reader plumbs the depth of Tish and Fonny's love, it becomes clear that Baldwin does not run away from sex. In a charged moment, the reader is invited to lean in and witness a private sexual encounter between a young Black couple. In a lengthy scene, Baldwin reveals the raw beauty of an intimate sexual experience that allows the reader to hear, identify, feel, and become emotionally involved in Tish's world-sense. By taking us deep into Tish memory, Baldwin prepares the reader for the profundity of her love for Fonny and how their physical connection contributes to, but does not define, the love she has for Fonny:

“... I need you. I love you". He smiled. "Is that all right, Tish?"

"Of course it's all right with me", I said. I had more to say, but my throat wouldn't open. He took me by the hand, then, and he led me to the pallet on the floor ... He kissed my face all over, and my neck, and he uncovered my breasts and put his teeth and tongue there and his hands were all over my body. I knew what he was doing, and I didn't know. I was in his hands, he called me by the thunder at my ear. I was in his hands: I was being changed; all that I could do was cling to him. I did not realize, until I realized it, that I was also kissing him, that everything was breaking and changing and turning in me and moving toward him. If his arms had not held me, I would have fallen straight downward, backward, to my death. My life was holding me.... When he came back, he was naked. He got under the shawl, with me, and stretched his long body on top of mine, and I felt his long black heavy sex throbbing against my navel.

He took my face in his hand, and held it, and he kissed me. "Now, don't be scared", he whispered. "Don't be scared. Just remember that I belong to you. Just remember that I wouldn't hurt you for nothing in this world. You just going to have to get used to me. 
And we got all the time in the world". It was getting to be between two and three: he read my mind. "Your Mama and Daddy know you're with me", he said, "and they know I won't let nothing happen to you". Then, he moved down and his sex moved against my opening. "Don't be scared", he said again. "Hold on to me".

I held on to him, in an agony; there was nothing else in the world to hold on to; I held him by his nappy hair. I could not tell if he moaned or if I moaned. It hurt, it hurt, it didn't hurt. It was a strange weight. a presence coming into me-into a me I had not known was there. I almost screamed, I started to cry: it hurt. It didn't hurt ... A singing began in me and his body became sacred - his buttocks, as they quivered and rose and fell, and his thighs between my thighs and the weight of his chest on mine and that stiffness of his which stiffened and grew and throbbed and brought me to another place I wanted to laugh and cry. Then, something absolutely new began, I laughed and I cried and I called his name. I held him closer and closer and I strained to receive it all, all, all of him. He paused and he kissed me and kissed me...

I said, "It was a little bit like being hit by a truck"—he laughed again- "but it was the most beautiful thing that ever happened to me". (Baldwin [1974] 2018, pp. 77-80)

The preceding passage demonstrates just how far Baldwin distanced himself and the character of Tish from Western discourse regarding the Black body. From a Western standpoint, sexual behavior is a form of domination, exploitation, and regulation to maintain power, but for Baldwin, this was just the opposite. Particularly frightening to the West was their conceptualization of the sexuality of the peoples they conquered. Clark, in Desire: A History of European Sexuality, suggests that "To justify their conquests, imperialist often portrayed colonized people as sexually barbaric" and controlled their bodies through rape and castration (Clark [2008] 2019, p. 84). Patricia Hill Collins, in Black Sexual Politics, also suggests, "Western religion, science, and media took over 350 years to manufacture an ideology of Black sexuality that assigned (heterosexual) promiscuity to Black people and then used it to justify racial discrimination" (Collins 2005, p. 98). Baldwin's description defies the stereotypes imported to justify such violence: Fonny is the furthest thing from a Mandingo Black Buck (Mitchell et al. 2016; Bogle 2001; Anderson et al. 2018), and the innocent and gentle affection Tish experiences defies categorizing her as an asexual Mammy, a rude and malicious Sapphire, or a lascivious Jezebel-all types used in the West to distort and silence the experiences and voices of Black women (Mitchell et al. 2016). Indeed, instead of the Western characterization of sex as rooted in domination and violence, Baldwin's narrative reveals only sexual liberation. The reader repeatedly encounters a mutual respect for the "presence" of the other person, and instead of viewing bodies being held hostage, the reader encounters mutual understanding and a sense of shared security. As salacious as the text may read, in between the lines-following Nash's (2014) The Black Body in Ecstasy: Reading Race, Reading Pornography research—Baldwin's narrative does not represent racialized pornography but an articulated, amplified, and practiced moment of agency and political freedom. Tish's first physical encounter with sex is transformed into a sacred spiritual and emotional experience of pleasure that honors the reality that she was a virgin.

The topic of sex and sexual behavior is not a new theme for Baldwin $(1953,1956,1962)$, although it takes on different directions in each of his novels. In Giovanni's Room (1956), there are both homosexual and heterosexual sex scenes, whereas in Go Tell It on the Mountain (1953), Baldwin shares limited details of Florence and her husband's intimate sexual encounters. In Another Country (1962), Rufus and Leona share a dramatic and powerful sexual encounter, and Richard, Cass, and Eric become entwined in a violent extramarital love affair. The literary critic Lorelei Cederstrom has observed that "[i]t should be evident by now that Baldwin is concerned with all aspects of human love and all the possibilities for human relationship" (Cederstrom 1984, p. 187). I agree, and maintain that in If Beale Street Could Talk, Baldwin mines a distinctly female African-centered perspective regarding the love Tish has for Fonny.

Of all the human love stories by Baldwin, I see in this novel an elevated conversation regarding intimacy and gender norms of what a Black female can experience. Baldwin uses this middle-class 
Black couple as a literary device to confront gendered and sexual stereotypes. His narrative aligns with Collins's narrative of rejecting images "depicting African American women as bitches; the sexual use of African American women's bodies by circulating images of Black women's promiscuity; [and] derogating the reproductive capacities of African American women's bodies" (Collins 2005, p. 137). Tish's sexual experience was both liberating and transformative instead of oppressive and controlled. Right before our eyes, we experience Tish emerge into the beauty of womanhood with her family's support. In just a few pages, she grows from a timid and delicate young girl into a mature woman, making the novel a coming-of-age story in addition to a love story. Tish's account of this transformative experience takes on even deeper meaning when Ernestine, Tish's sister, who jokingly refers to Tish as "Jezebel" because of her perfume store job, boldly tells Tish to "Unbow your head, sister" for she is a woman proudly making her own choices. Instead of violence and domination, instead of words and understanding, Tish is left with an experience of Fonny's body that "was a total mystery to me" and a world-sense that is not defined in physical terms (the loss of her virginity) but rather the discovery of "the gravest mystery of one's life" - that knowledge of another is always out of one's grasp (Baldwin [1974] 2018, pp. 81-82). From this initial sexual experience, Tish and Fonny's relationship will continue to develop. They would later work towards marriage, secure a home together, and conceive a child. However, regardless of their outward conformity to Western standards, inwardly Tish will always be in a process not of knowing Fonny but of re-discovering his beautiful "presence" again and again.

Baldwin's approach aligns with bell hooks's understanding of liberating Black love for Black Women. Hooks argues "black females must constantly assert our full humanity to counter the impact of dehumanizing forces. Expressing our full range of emotions is healing to the spirit and engages us in the practice of self-acceptance" (Hooks 2001, p. 112). Baldwin dictates this love scene through Tish's gaze and her desires. The intimate and honest love of a Black Women taking up space on multiple pages for many seems insignificant, yet Tish is not a victim or survivor; she is a loud and outspoken active participant. As Tish narrates the moment as Fonny led the way, what was happening was not controlled or regulated. At the end, Tish states, "It was a little bit like being hit by a truck ... but it was the most beautiful thing that ever happened to me" (Baldwin [1974] 2018, p. 80). In the end, Tish confers the language of beauty on herself, recognizing that her "presence" has been transformed as a result of the encounter.

\section{Conclusions}

Baldwin explicitly states that "our real responsibility is to endlessly redefine each other" (Lorde and Baldwin 1984, p. 50). Although upon its publication critics were unable to see Baldwin's vision to liberated black bodies, since then times have changed. A shining testament of the corrected interpretation I am proposing in this note can be seen in Barry Jenkins' recent cinematic treatment of the novel, where critics finally heard Tish's voice and grasped Baldwin's project. "Jenkins has adapted Beale Street in the spirit of its author's vision", wrote Kinohi Nishikawa in Slate. "Most notably, he emphasizes, rather than diminishes, Tish's point of view". He goes on to observe that "Jenkins' film takes the young heroine at her word against a tradition of reading her suspiciously". Writing in the New York Times, Manohla Dargis also rejected the earlier simplistic readings of the novel: "This romantically swoony vision of the beloved seems like a reverie from a bohemian fantasy ... Except that Fonny and Tish are loving while black, an existential truth that is turned into a nightmare". (p. C5). She goes on to recognize how Jenkins used Tish to guide the viewer through the narrative and compliments his recognition of the silences in the novel as communicating meaning:

In "Beale Street", Jenkins is inviting you to look deeply at these men and women, to see how they look to, and at, each other. He does this primarily through an expressionist visual style that can make words superfluous. (Dargis 2018, p. C5) 
Indeed, Dargis seems to channel the language of Africana Studies in her description of Fonny in Tish's eyes: "Fonny looks beautiful, holy ... sanctified ... by the love of a woman" (Dargis, p. C5). Her summation of the romantic plot captures the sense of how Tish and Fonny's love embarrasses an African-centered world-sense of love:

In most white screen romances, the love between a man and a woman (and its tests) tends to be framed in personal terms, as a matter of individual will, of good or foolish choices of the heart and head. The greater world always presses in on the star-crossed lovers even when the movie pretends otherwise, shaping or just quietly tugging at their story. Here, the world-white, pitiless, punishing — comes down like a hammer on Fonny and Tish. Because no matter the purity and grace of their love when they wander the Village, or eat in a friendly Spanish restaurant that was a Baldwin favorite, they are never simply two people in love but also an affront to the power of the white world.

Other critics complimented Jenkins for visually capturing Baldwin's expressions of Black sexuality rather than responding to or repeating stereotypical Western norms of the Black body. "The film's fidelity to its source material points to an appreciation for what was there all along" (Nishikawa 2019).

Writing and filming against this Western backdrop of biological determinism, If Beale Street Could Talk rejects centering Black sexual politics as grounded in the physical body. The reader and viewer become enmeshed in the world-sense discourses of sex and sexuality, rooted instead in spirituality, love, and wonder. In multiple moments, bodies are not seen and words are not spoken, yet sexual feelings are expressed though motion, dreams, silence, and even a simple gaze. "In 'Beale Street'", Dargis writes, "Jenkins is inviting you to look deeply at these men and women, to see how they look to, and at, each other". Nishikawa declared the film "a revelation" in how it illuminated what was previously "neglected" in Baldwin's novel. Both the book and the film "refuse to appeal to the white gaze. It's a story of black love, and of black struggle, that doesn't wait for viewers who need catching up" (Nishikawa 2019).

In his writing, Baldwin illuminates the tensions surrounding the social constructions of race, class, gender, and even law. However, it is in the ideas of love and sex that I believe Baldwin is the most revolutionary. Emerging at a time in society when progress dominated Black culture, If Beale Street Could Talk charts a course for the reclamation and re-imagination of Black sexual politics. As a homosexual Black male writer, Baldwin articulated a visual and invisible, spoken and unspoken sexual discourse, philosophy, and behavior represented through the gaze of a heterosexual Black woman. Yet, in the wake of the \#MeToo Movement and allegations of sexual harassment, Black women today continue to face the marginalization of not being seen and heard. One of the most depressing scenes in the novel is when Tish's mother Sharon, in somewhat of a shameful and hesitant manner, insists to Fonny's accuser Victoria that Fonny did not rape her. In that moment, it is revealed that the white police officer told Victoria to pick Fonny out, leaving Sharon helpless and silent, with systematic racism silencing Black women's voices.

To the extent that If Beale Street Could Talk employs an African world-sense notion of Black love, the novel still remains stuck in the social dilemma of American racism and patriarchy. Black love is real, evident, and long lasting, yet still is a struggle. Existential struggles offer no comforting promises-love prevails, but justice does not in Baldwin's fiction. However, as Baldwin writes in another letter to his brother David, "I think we have to try. Innumerable human beings are being destroyed, in silence. We can't unlock the prison gates, but perhaps we can begin to break the silence"' (Baldwin 1973).

Funding: This research received no external funding.

Conflicts of Interest: The author declares no conflict of interest. 


\section{References}

Ackroyd, Peter. 1974. A Little Black Magic. The Spectator, July 6, p. 22.

Anderson, Joel R., Elise Holland, Courtney Heldreth, and Scott P. Johnson. 2018. Revisiting the Jezebel Stereotype. Psychology of Women Quarterly 42: 461-76. [CrossRef]

Austin, Colin, and S. Douglas Olson. 2004. Aristophanes Thesmorphoriazusae. Oxford: Oxford University Press on Demand. Azibo, Daudi Ajani ya. 1992. Articulating the Distinction between Black Studies and the Study of Blacks: The Fundamental Role of Culture and the African-Centered Worldview. The Afrocentric Scholar 1: 64-97.

Baldwin, James. 2018. If Beale Street Could Talk. Edited by Vintage International Movie Tie-In. New York: Vintage International. First published 1974.

Baldwin, James. 1953. Go Tell it on the Mountain. New York: Grosset \& Dunlap.

Baldwin, James. 1955. Notes of a Native Son. Boston: Beacon Press.

Baldwin, James. 1956. Giovanni's Room. New York: Dial Press.

Baldwin, James. 1962. Another Country. London: Penguin Books.

Baldwin, James. 1973. Letters of James Baldwin. Atlanta: Stuart A Rose Manuscript Archives \& Rare Book Library.

Balfour, Katharine Lawrence, and Lawrie Balfour. 2001. The Evidence of Things Not Said: James Baldwin and the Promise of American Democracy. Ithaca: Cornell University Press.

Bogle, Donald. 2001. Toms, Coons, Mulattoes, Mammies, and Bucks: An Interpretive History of Blacks in American Films, 5th ed. London: Bloomsbury Academic.

Broyard, Anatole. 1974. No Color Line in Clichés: Books of the Times Sentimental Love Story Adverbs Stalk Menacingly. New York Times (1923-Current File), May 17, p. 37.

Carr, Greg. 2006. Teaching and Studying the Africana Experience. School District of Philadelphia Africana Studies Curriculum. 12-20. Available online: https://web.archive.org/web/20141008004126/http://webgui.phila.k12. pa.us/offices/c/curriculum/curriculum-supports/course-african-american (accessed on 4 December 2019).

Cederstrom, Lorelei. 1984. Love, Race and Sex in the Novels of James Baldwin. Mosaic: A Journal for the Interdisciplinary Study of Literature 17: 175-88.

Clark, Anna. 2019. Desire: A History of European Sexuality. New York: Routledge. First published in 2008.

Collins, Patricia H. 2005. Black Sexual Politics. New York: Routledge.

Dargis, Manohla. 2018. Love Is Forced to Live in a Nightmare. The New York Times, December 14, p. C5.

Davidson, James N. 2007. The Greeks and Greek Love, 1st ed. New York: Random House.

Gounard, Jean-François. 1992. The Racial Problem in the Works of Richard Wright and James Baldwin, 1st ed. Contributions in Afro-American and African Studies. Westport: Greenwood Press, vol. 140.

Gyekye, Kwame. 1995. An Essay on African Philosophical Thought: The Akan Conceptual Scheme. Philadelphia: Temple University Press.

Hallen, Barry. 2000. The Good, the Bad, and the Beautiful Discourse about Values in Yoruba Culture. Bloomington: Indiana University Press.

Hammonds, Evelynn M. 1999. Toward a Genealogy of Black Female Sexuality: The Problematic of Silence. In Feminist Theory and the Body, 1st ed. London: Routledge, pp. 93-104.

Higginbotham, Evelyn Brooks. 1989. Beyond the Sound of Silence: Afro-American Women in History. Gender $\mathcal{E}$ History 1: 50-67.

Hogan, Patrick. 2001. Philosophical Approaches to the Study of Literature. Gainesville: University Press of Florida.

Hooks, Bell. 2001. Salvation: Black People and Love. London: Women's Press.

Kenyatta, Jomo. 1962. Facing Mount Kenya: The Tribal Life of the Gikuyu. New York: Vintage Books.

Laqueur, Thomas Walter. 1990. Making Sex: Body and Gender from the Greeks to Freud. Cambridge: Harvard University Press.

Lorde, Audre, and James Baldwin. 1984. Revolutionary Hope: A Conversation between Audre Lorde \& James Baldwin. Mosaic Literary Magazine 15: 42-52.

McBride, Dwight A. 1999. James Baldwin Now. New York: New York University Press.

Miller, D. Quentin. 2012. A Criminal Power: James Baldwin and the Law. Columbus: Ohio State UP.

Mitchell, Roland W., Heidi R. Lewis, Takiyah Nur Amin, Velva Boles, Catherine M. Pears, Jean Gumpper, Kate Leonard, Sha'Condria Sibley, Karen Riley Simmons, and Claudine Taaffe. 2016. Beyond Mammy, Jezebel $\mathcal{E}$ Sapphire: Reclaiming Images of Black Women. Portland: Jordan Schnitzer Family Foundation.

Nash, Jennifer. 2014. The Black Body in Ecstasy: Reading Race, Reading Pornography. Durham: Duke University Press. 
Nishikawa, Kinohi. 2019. James Baldwin's Beale Street Flopped in 1974. Here's how Barry Jenkins' Film Reveals it as a Timely Masterpiece. Slate Magazine. Available online: https://slate.com/culture/2019/01/beale-streetbaldwin-jenkins-book.html (accessed on 22 June 2019).

Oates, Joyce Carol. 1974. If Beale Street Could Talk: By James Baldwin. New York: The Dial Press, 197p.

Okpewho, Isidore. 1992. African Oral Literature. Bloomington: Indiana University Press.

Oyěwùmí, Oyèrónké. 1997. Invention of Women: Making an African Sense of Western Gender Discourses, New ed. Minneapolis: University of Minnesota Press.

Puzo, Mario. 1968. His Cardboard Lovers: Tell me how long the train's been gone. Edited by James Baldwin. New York Times, June 23, p. 484.

Roberts, Dorothy. 2007. Killing the Black Body: Race, Reproduction, and the Meaning of Liberty. New York: Vintage Books. First published 1997.

Skinner, Marilyn B. 2005. Sexuality in Greek and Roman Culture. Malden: Wiley Blackwell.

Turner, Bryan S. 2008. The Body \& Society, 3nd ed. Los Angeles: SAGE.

Winkler, John J. 2013. The Constraints of Desire: The Anthropology of Sex and Gender in Ancient Greece. London: Routledge. Youngquist, Paul, and Frances Botkin. 2011. Introduction: Black Romanticism: Romantic Circulations. In Circulations: Romanticism and the Black Atlantic. Edited by Paul Youngquist and Frances Botkin. Boulder: University of Colorado Boulder, pp. 1-30.

(C) 2020 by the author. Licensee MDPI, Basel, Switzerland. This article is an open access article distributed under the terms and conditions of the Creative Commons Attribution (CC BY) license (http://creativecommons.org/licenses/by/4.0/). 